Selcuk Journal of Agriculture and Food Sciences

http://sjafs.selcuk.edu.tr/sjafs/index

Research Article
SJAFS

(2021) 35 (2), 108-114

e-ISSN: $2458-8377$

DOI:10.15316/SJAFS.2021.236

\title{
Population Development and Infestation Rate of Codling Moth (Cydia Pomonella (Lepidoptera: Tortricidae)) In Apple Orchards in Northern Kyrgyzstan $^{* *}$
}

\author{
iD Tair ESENALI UULU ${ }^{1, *}$, (D) Levent ÜNLÜ ${ }^{2}$ \\ ${ }^{1}$ Kyrgyz-Turkish Manas University, Faculty of Agriculture, Department of Plant Protection, Bishkek, Kyrgyzstan \\ ${ }^{2}$ Selçuk University, Faculty of Agriculture, Department of Plant Protection, Konya, Turkey
}

\begin{tabular}{l}
\hline ARTICLE INFO \\
\hline Article history: \\
Received date: 15.04 .2021 \\
Accepted date: 11.06 .2021 \\
\hline
\end{tabular}

Keywords:

Cydia pomonella

Monitoring

Sex pheromones

Damage

Kyrgyzstan

\begin{abstract}
The codling moth is a key and most widely distributed pest of apple orchards worldwide. The population development of $C$. pomonella was investigated using sex pheromone traps in different apple orchards between years of 2019 and 2020 in northern Kyrgyzstan. Flight of the codling moth males in apple orchards is characterized by instability, which is associated with temperature and other climatic factors. Trap captures of codling moth were positively correlated with temperature, but negatively correlated with relative humidity and altitude. Male moths started appearing in traps on April 10-14, 2019 and April 26-29, 2020 in Chui and Ysyk-Kol provinces. Analysis of seasonal trap catches from apple orchards over two years summarizes that the codling moth has 4 major peaks in Chui and 3 distinct peaks in Ysyk-Kol provinces. Codling moth damage per orchard ranged from $8.3 \%$ to $84.3 \%$ in Chui province and it was estimated per orchard from $1.4 \%$ to $27.2 \%$ in Ysyk-Kol province.
\end{abstract}

\section{Introduction}

Apple is one of the most widely produced and economically important fruit crops in temperate regions around the world. Cultivated apple (Malus domestica Borkh.), which is the oldest fruit crop used as a cultivated plant, has been domesticated from Malus sieversii in the Tian Shan Mountains for 4000-10,000 years and dispersed from Central Asia to West Europe along the Silk Road (Cornille et al. 2014; Duan et al. 2017). Since the homeland of the apple is Central Asia, it has been reported by the researchers that some pests and diseases of apple trees are unique to Central Asia, and it is still the subject of great interest for research (Luby et al. 2001; Mills 2005).

Codling moth, Cydia pomonella L. (Lepidoptera: Tortricidae), originated from Central Asia is a key and most widely distributed pest of apple orchards worldwide (Barnes 1991; Mills 2005). Its host range is restricted mainly on apple, pear, crabapple, quince, hawthorn, and walnut, with one to four generations a year in the palearctic zone (Johnson 2013). Codling moth adult females lay eggs on the fruit or leaf surface, hatched larvae mostly bore directly into the fruits and eats the seeds inside the fruits. There are five larval

\footnotetext{
* Corresponding author email: tair.esenaliuulu@manas.edu.kg
}

**This work is part of first author's PhD thesis instars, at maturity, larvae usually leave the fruits and usually pupate under the bark. Codling moth overwinters as mature diapausing larvae in cocoons until climatic conditions are suitable for adults to fly (Welter 2009).

Pest monitoring is a fundamental component of IPM programs and sex pheromones are the best tools to monitor the seasonal flight periods of pests, and they are widely used in a variety of ways in pest control programs in agricultural crops (Fadamiro 2004). Sex pheromones are nontoxic and species-specific blends, which produced by adult females in order to attract males for mating (Baker and Heath 2005). Captures in traps baited with synthetic pheromone lures accurately show whether a specific insect is present, provide reliable information about seasonal activity of pests and effective time of insecticide sprays (Witzgall 2010). Numerous studies were conducted to determine the population development and infestation rate of C. pomonella in the different region of the world using sexual pheromones (Fadamiro 2004; Mamay and Yanık 2013; Zada et al. 2014; Aydoğan and Ünlü 2019)

In Kyrgyzstan, apple production is small (135 ths tons/year) and unstable due to yield and quality loss from key pests and diseases. Although C. pomonella is considered to be a key pest, no scientific studies have been conducted on this pest last 30 years and the present situation of the pest in the region is not known clearly. Studies conducted earlier than 1990 or during 
USSR time have mainly focused on determining the pest population with the help sum of effective temperatures or light traps (Vasilev and Pristavko 1970; Mamaev 1981). According to the information we obtained from the literature we could reach; the pest population development was not determined using sex pheromones at least in Kyrgyzstan. Consequently, there lack effective pest management programs against this pest for growers, and efforts to control the codling moth relies mostly intensive use of broad-spectrum insecticide sprays throughout the growing season, which has resulted in the development of insecticide resistance, and an increase in the abundance of secondary pests (Vreysen et al. 2010).

The aim of this study was: (1) to monitor population development, and (2) to estimate the damage of codling moth in apple-growing regions of northern Kyrgyzstan. We consider flight pattern information of pest and other observations obtained through this study will be useful in determining the control methods against this pest.

\section{Materials and Methods}

\section{Population development}

This study was conducted from April 2019 to October 2020 in three apple orchards in Chui province, and five in Ysyk-Kol province (YK), North Kyrgyzstan. Orchards' main characteristics and pest control informations are given in Table 1. Populations of adult codling moths were determined from the catches of male moths using delta-type pheromone traps for two years. In all traps, sticky trays were used for catching and counting, and species-specific pheromone capsules, which contain 1,5 mg E.E-8.10-dodecadien-1-ol, also known as codlemone (Russell IPM Ltd., Deeside,

Table 1

Location, main characteristics and pest control information's of apple orchards.

\begin{tabular}{|c|c|c|c|c|c|c|c|}
\hline $\begin{array}{l}\text { Name of } \\
\text { orchard }\end{array}$ & Lat $\left({ }^{\circ} \mathrm{N}\right)$ & Lon $\left({ }^{\circ} \mathrm{E}\right)$ & $\mathrm{Al}(\mathrm{m})$ & $\begin{array}{l}\text { Size } \\
\text { (ha) }\end{array}$ & $\begin{array}{l}\text { Age of } \\
\text { trees } \\
\text { (y.old) }\end{array}$ & Varieties & Insecticide application \\
\hline \multicolumn{8}{|l|}{2019} \\
\hline Chui-1 & $42^{\circ} 54^{\prime} 16^{\prime \prime}$ & $74^{\circ} 48^{\prime} 21^{\prime \prime}$ & 731 & 0.7 & $12-15$ & $\begin{array}{l}\text { Semerenko, Pre, R.d, G, } \\
\text { İdared }\end{array}$ & $\begin{array}{l}\text { (1) imidacloprid; } \\
\text { (2) lambda-cyhalothrin }\end{array}$ \\
\hline Chui-2 & $42^{\circ} 49^{\prime} 12^{\prime \prime}$ & $74^{\circ} 38^{\prime} 21^{\prime \prime}$ & 878 & 1.5 & $20-25$ & Aport, Pre, K.z & No ins. application \\
\hline Chui-3 & $42^{\circ} 55^{\prime} 53^{\prime \prime}$ & $74^{\circ} 49^{\prime} 42^{\prime \prime}$ & 1313 & 5 & $35-40$ & Aport, Pre, K.z & No ins. application \\
\hline YK-1 & $42^{\circ} 10^{\prime} 02^{\prime \prime}$ & $77^{\circ} 37^{\prime} 02^{\prime \prime}$ & 1696 & 0.5 & $15-20$ & Makintosh, K.z, Pre & thiacloprid \\
\hline YK-2 & $42^{\circ} 18^{\prime} 27^{\prime \prime}$ & $77^{\circ} 52^{\prime} 57^{\prime \prime}$ & 1733 & 1.5 & $25-30$ & Pre, Aport & thiacloprid \\
\hline YK-3 & $42^{\circ} 25^{\prime} 43^{\prime \prime}$ & $78^{\circ} 12^{\prime} 11^{\prime \prime}$ & 1760 & 1 & $20-25$ & Pre, Aport, K.z & dimethoate \\
\hline YK-4 & $42^{\circ} 46^{\prime} 24^{\prime \prime}$ & $77^{\circ} 43^{\prime} 57^{\prime \prime}$ & 1780 & 0.6 & $25-30$ & Zolotoy Ranet, Pre, Aport & No ins. application \\
\hline YK-5 & $42^{\circ} 45^{\prime} 10^{\prime \prime}$ & $77^{\circ} 39^{\prime} 26^{\prime \prime}$ & 1688 & 3 & 4 & İ, Pre, G, Krimson & No ins. application \\
\hline \multicolumn{8}{|l|}{2020} \\
\hline Chui-2 & $42^{\circ} 49^{\prime} 12^{\prime \prime}$ & $74^{\circ} 38^{\prime} 21^{\prime \prime}$ & 878 & 1.5 & $20-25$ & Aport, Pre, K.z & No ins. application \\
\hline Chui-3 & $42^{\circ} 55^{\prime} 53^{\prime \prime}$ & $74^{\circ} 49^{\prime} 42^{\prime \prime}$ & 1313 & 5 & $35-40$ & Aport, Pre, K.z & No ins. application \\
\hline YK-2 & $42^{\circ} 18^{\prime} 27^{\prime \prime}$ & $77^{\circ} 52^{\prime} 57^{\prime \prime}$ & 1733 & 1.5 & $25-30$ & Pre, Aport & lambda-cyhalothrin \\
\hline
\end{tabular}

Pre: Prevoshod, R.d: Red Delicious, G: Golden, I: Idared, K.z: Kirgizskiy Zimniy

Statistical analysis was conducted using SPSS v.22.0 (IBM, Armonk, NY, USA). The significance of altitude on the number of male catches in monitoring traps was determined by correlation (Pearson) and regression analysis at $P=0.05$ for the multiple com-
Flintshire, UK) used to attracting codling moth males to the traps. The traps were hung at $1.5-2 \mathrm{~m}$ high from the ground in the south direction of the trees and in the direction of the dominant wind. Trap visits were performed every day of week until the first adult was captured, and once a week after the first adult was captured, the number of captured adults were recorded. The pheromone capsules of the traps were replaced every six weeks and old capsules were removed from the orchards. The sticky trays in the traps were replaced with new ones as needed depending on the loss of the adhesive layer (Knight et al. 2009; Çelik and Ünlü 2017).

\section{Infestation rate and data analysis}

To estimate the level of infestation, the damage to fruits caused by the codling moth was surveyed in July and September, in two consecutive years (2019, year 1; 2020, year 2). Different sampling methods can be used to determine the infestation rate of $C$. pomonella. Three different methods; 'Tree-Based', 'Fruit-Based' and 'Crate-Based', are commonly used to determine the codling moth infestation rates (Mamay and Yanık 2013). In this study 'Fruit-Based' method was used to determine the infestation rate of the pest. In total, approximately 100 fruits were randomly collected from 5 trees in the center of each orchard each time and holes of codling moth larvae were determined from visual examination of each apple in a sample. Only apples that attached to the tree were assessed for larval infestation. The level of infestation (\%) was calculated by the equation:

Level of Infestation $(\%)=(\mathrm{Ni} / \mathrm{Nc}) \times 100$

where $\mathrm{Ni}$ is the number of damaged fruits and $\mathrm{Nc}$ is the number of collected fruits in orchard. 
differences of damage rates between orchards and provinces.

\section{Results and Discussion}

\section{Population development}

Pheromone traps were installed at apple orchards and used to monitor $C$. pomonella populations in Chui and Ysyk-Kol provinces from April to October in 2019 (24 traps) and 2020 (9 traps) (Fig. 1; Fig. 2). Results from two-year study showed the detection of four major peaks (late April - early May, late May - early June, late June - early July, and early August - mid August) and three distinct peaks (late May - early June, late June - early July and late July - early August) of the pest in Chui and Ysyk-Kol provinces, respectively.

Chui province. In 2019, the first codling moth catch in Chui-1, Chui-2 and Chui-3 orchards were April $11^{\text {th }}$, April $13^{\text {th }}$, and April $14^{\text {th }}$, respectively. But, in 2020, moths started appearing in traps a week later than
2019, on April 21 and April 20 in Chui-2 and Chui-3 orchards, respectively. In Chui-1 orchard, a total of $259 \pm 12.6$ (Mean \pm SE) males were caught in pheromone traps in 2019, with four peaks on April 14, May 15, June 19, and July 31 (Fig 1; Fig 2; Table 2). In 2020, monitoring has not carried out in this orchard due to regularly visiting problems. The total captured adult male moths' number were $1089 \pm 119.8$ and $779 \pm 31.39$ in Chui-2 orchard, in 2019 and 2020, respectively. According to trap data, four major peaks of the population were established in Chui-2 orchard, on May $5^{\text {th }}$, May 29th, June 22 and July 31 in 2019 and May 12, June 16, July 21, August 18 in 2020 (Fig 1; Fig 2; Table 2). The Chui-3 orchard has the highest pest population among all orchards, with four peaks on May 8, June 5, July 10 and August 14 in 2019 and May 12, June 23, July 28, and August 25 in 2020 (Fig 1; Fig 2; Table 2). The total captured moths were $1287 \pm 99.3$ and $823 \pm 36.7$ in 2019 and 2020, respectively.

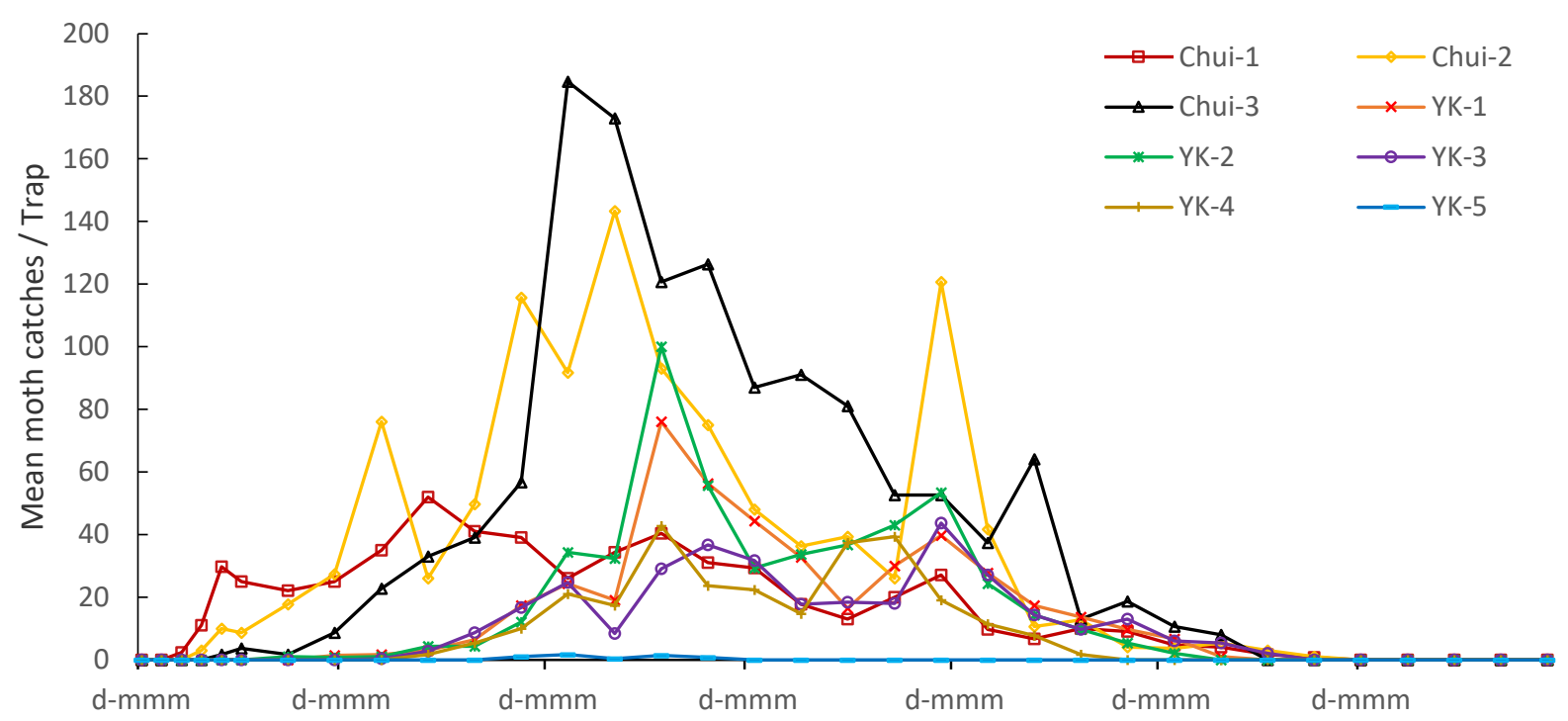

Figure 1

Population development of Cydia pomonella in apple orchards in Chui and Ysyk-Kol provinces in 2019. Each observation represents a mean of three replications.

Ysyk-Kol province. In 2019, population of codling moth monitored at 5 different orchard, and pest flight pattern was nearly similar in all orchards. The first codling moth catch in traps in YK-1, YK-2, YK-3, and YK-4 orchards were May 3, April 26, May 14, and May 18, respectively (Fig 1). The total captured adult male moths' number in YK-1, YK-2, YK-3, and YK-4 orchards were $444 \pm 36.7,497 \pm 45.4,333 \pm 18.2$, and $275 \pm 15.9$. In 2019 , adults of codling moth were caught with the main and first peak on late of May and then undergone two more generations (late June - early July and late July - early August) in YK-1, YK-2, YK-3, and YK-4 orchards in Ysyk-Kol province (Fig 1; Table 2). In YK-5 orchard, a total of only 15 male codling moths were caught in three pheromone traps, starting from May 31 till June 22. The reason for this low population probably is due to the age of this orchard. In 2020, population monitoring was carried out in only one orchard (YK-2), because of codling moth flight pattern similarity in 2019 and regularly visiting problems due to global pandemic condition. Codling moth appeared from April 29 and showed three peaks until late August.

According to results, trap captures were positively correlated with temperature $(\mathrm{r}=0.550 ; P=0.001$ in Chui and $\mathrm{r}=0.558 ; P=0.001$ in Ysyk-Kol in 2019; $\mathrm{r}=$ $0.480 ; P=0.001$ in Chui and $r=0.228 ; P=0.001$ in Ysyk-Kol in 2020) and negatively correlated with relative humidity $(\mathrm{r}=-0.282 ; P=0.001$ in Chui and $\mathrm{r}=$ $0.359 ; P=0.001$ in Ysyk-Kol in 2019; $\mathrm{r}=-0.270 ; P=$ 0.001 in Chui and $\mathrm{r}=-0.288 ; P=0.001$ in Ysyk-Kol in 2020). Temperature data are given in Fig 3. 


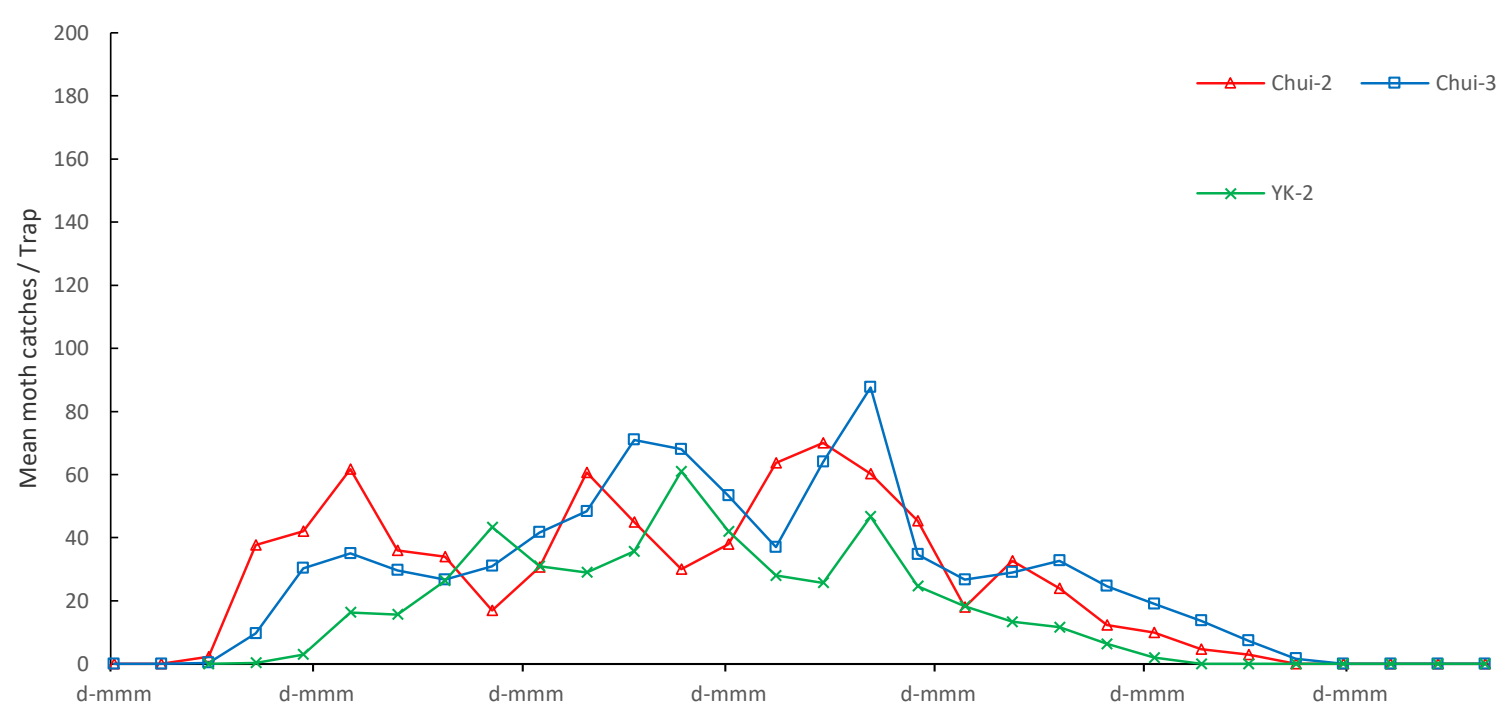

Figure 2

Population development of Cydia pomonella in apple orchards in Chui and Ysyk-Kol provinces in 2020. Each observation represents a mean of three replications.

Table 2.

Population events (Mean \pm SD) of codling moth in apple orchards in Chui and Ysyk-Kol in 2019 and 2020.

\begin{tabular}{|c|c|c|c|c|c|c|c|}
\hline Province & Orchard & Year & $1^{\text {st }}$ catch & $1^{\text {st }}$ peak & $2^{\text {nd }}$ peak & $3^{\text {rd }}$ peak & $4^{\text {th }}$ peak \\
\hline \multirow{6}{*}{ Chui } & \multirow{2}{*}{ Chui-1 } & 2019 & $3.33 \pm 1.52$ & $25.6 \pm 3.18$ & $40.3 \pm 8.74$ & $20 \pm 2.4$ & $10.5 \pm 6.92$ \\
\hline & & 2020 & - & - & - & - & - \\
\hline & \multirow{2}{*}{ Chui-2 } & 2019 & $10 \pm 4.32$ & $27.3 \pm 2.86$ & $115.7 \pm 29.4$ & $75 \pm 16.8$ & $62.7 \pm 13.9$ \\
\hline & & 2020 & $2.33 \pm 1.15$ & $61.7 \pm 22 \pm 85$ & $60.7 \pm 19.01$ & $63.7 \pm 14.9$ & $32.7 \pm 8.96$ \\
\hline & \multirow{2}{*}{ Chui-3 } & 2019 & $1.95 \pm 3.01$ & $13.93 \pm 13.44$ & $184.7 \pm 6.18$ & $91 \pm 7.88$ & $64.5 \pm 12.4$ \\
\hline & & 2020 & $9.7 \pm 5.03$ & $35 \pm 6$ & $41.7 \pm 10.7$ & $71 \pm 12.49$ & $87.7 \pm 12.42$ \\
\hline \multirow{10}{*}{ Ysyk-Kol } & \multirow{2}{*}{ YK-1 } & 2019 & $1.33 \pm 1.24$ & $24.3 \pm 10.8$ & $76 \pm 26.05$ & $39.6 \pm 7.09$ & - \\
\hline & & 2020 & - & - & - & - & - \\
\hline & \multirow{2}{*}{ YK-2 } & 2019 & $4.3 \pm 3.24$ & $34.3 \pm 5.50$ & $100 \pm 7.93$ & $53.3 \pm 13.61$ & - \\
\hline & & 2020 & $3 \pm 1.73$ & $43.4 \pm 7.09$ & $61 \pm 11.1$ & $46.7 \pm 10.1$ & - \\
\hline & \multirow{2}{*}{ YK-3 } & 2019 & $2.66 \pm 1.52$ & $24.66 \pm 7.50$ & $36.6 \pm 4.93$ & $43.7 \pm 7.37$ & - \\
\hline & & 2020 & _. & - & - & _- & _ \\
\hline & \multirow{2}{*}{ YK-4 } & 2019 & $5.33 \pm 3.05$ & $21 \pm 10.44$ & $42.7 \pm 13.31$ & $39.3 \pm 4.16$ & - \\
\hline & & 2020 & - & - & - & - & - \\
\hline & \multirow{2}{*}{ YK-5 } & 2019 & $0.7 \pm 1.15$ & $1.7 \pm 1.15$ & - & - & - \\
\hline & & 2020 & - & - & - & - & - \\
\hline
\end{tabular}

Correlation studies revealed that codling moth adult catches had negative correlation with altitude in all orchards $(\mathrm{r}=-0.571 ; P=0.013)$. The overall regression analysis was statistically significant $(\mathrm{F}=7.34, p<0.006$, $\left.\mathrm{R}^{2}=0.50\right)$. Detailed regression values are given in Table 3 .

\section{Infestation rate}

Codling moth damage to apples was not significantly different between years $(d f=26 ; t=-3.19 ; p=0.531)$, but it did vary significantly between orchards $(d f=6$; chi-square $=18.488 ; p=0.005)$ and provinces $(d f=1$; chi-square $=7.350 ; p=0.007$ ) each year (Table 4$)$. In Chui Province, CM damage per orchard ranged from $8.3 \%$ to $84.3 \%$ and from $15.4 \%$ to $77.1 \%$ in 2019 and 2020, respectively. But, in Ysyk-Kol province it was estimated per orchard from $1.4 \%$ to $20.6 \%$ and from
$5.3 \%$ to $27.2 \%$ in 2019 and 2020, respectively. Damage, in general, was greater in Chui province $(47.03 \% \pm 26.01$; mean \pm SD) than in Ysyk-Kol $(14.08 \% \pm 8.64)$. Moreover, damage was higher in 2020 $(31.15 \% \pm 22.25 ;$ mean \pm SD) than in 2019 $(25.23 \% \pm 26.75)$.

The most widespread and ubiquitous use of sex pheromones has been detection and population monitoring. In pest management programs, population monitoring using sex pheromone is necessary to determine thresholds, to schedule insect control applications on time (Baker and Heath 2005). In this study, we monitored seasonal flight patterns of $C$. pomonella and estimated its damage status in apple orchards in northern Kyrgyzstan. 

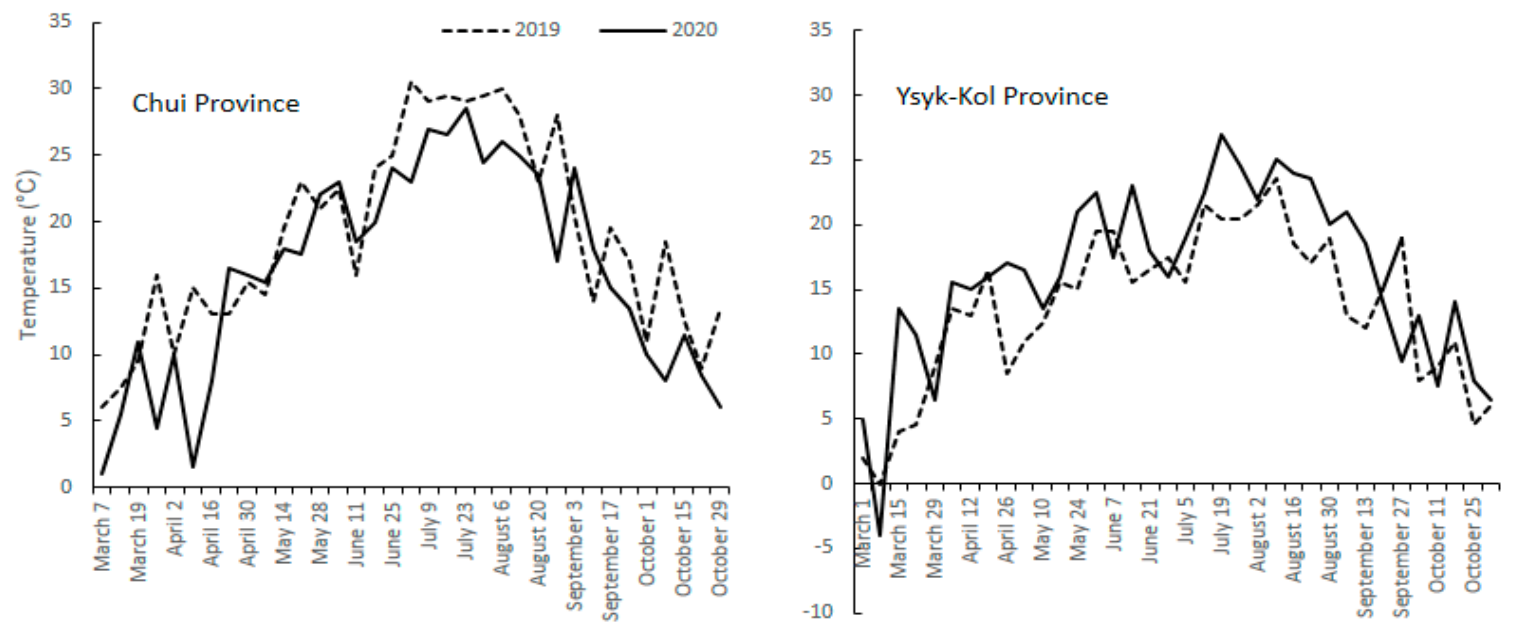

Figure 3

Temperature data of Chui and Ysyk-Kol from Bishkek and Cholpon-Ata Meteorological Station, 2019 and 2020.

Our data on seasonal abundance indicated that the flight of the codling moth males in apple orchards is characterized by instability, which is associated with temperature and other climatic factors. Trap capture results showed 3-4 and 2-3 peaks of codling moth in Chui and Ysyk-Kol provinces. Thus, based on the above material, it can be noted that the codling moth developed in three and two generations in a year in Chui and Ysyk-Kol provinces, respectively. Similar results noted by Konurova et al. (2017) that codling moth able to develop three generations in Chui valley.
Numerous reports have been published (Riedl and Croft 1978; Blomefield et al. 1997; Reuveny and Cohen 2004; Aydoğan and Ünlü 2019) dealing with codling population under similar climate with Kyrgyzstan, which shows codling moth is essentially bivoltine with considerable yearly variability in third generation emergence. That the very low number of male codling moths caught in traps at YK-5, compared to the other orchards, is likely an indicator that the population of codling moth is not settled yet due to age of trees.

Table 3

Comparison of total mean moth catches of Cydia pomonella at different altitude using delta pheromone traps during 2019 and 2020.

\begin{tabular}{|c|c|c|c|c|c|}
\hline Site / Year & $\begin{array}{l}\text { Altitude } \\
\text { (m a.s.l) }\end{array}$ & $\mathrm{N}$ & Monitoring Period & $\begin{array}{l}\text { Total captured males } \\
(\text { Mean } \pm \text { SE) }\end{array}$ & Anova \\
\hline Chui-2 / 19 & 878 & 3 & March - November & $1089.3 \pm 119.9$ & $\mathrm{~F}=5.69, p<.048, \mathrm{R}^{2}=.049$ \\
\hline Chui-2 / 20 & 878 & 3 & March - November & $779 \pm 31.3$ & $\mathrm{~F}=8.16, p<.024, \mathrm{R}^{2}=.054$ \\
\hline Chui-3 / 19 & 1313 & 3 & March - November & $1287.6 \pm 99.3$ & $\mathrm{~F}=5.69, p<.048, \mathrm{R}^{2}=.049$ \\
\hline Chui-3 / 20 & 1313 & 3 & March - November & $823 \pm 36.6$ & $\mathrm{~F}=8.16, p<.024, \mathrm{R}^{2}=.054$ \\
\hline YK-2 / 19 & 1733 & 3 & April - November & $497.3 \pm 45.4$ & $\mathrm{~F}=5.69, p<.048, \mathrm{R}^{2}=.049$ \\
\hline YK-2 / 20 & 1733 & 3 & April - November & $535 \pm 35.3$ & $\mathrm{~F}=8.16, p<.024, \mathrm{R}^{2}=.054$ \\
\hline
\end{tabular}

$\mathrm{N}$ : number of replications

Some factors such as photoperiod and temperature are known to play a key role in codling moths' seasonal activity (Setyobudi, 1989). In our study, trap captures of codling moth were positively correlated with temperature, but negatively correlated with relative humidity and altitude. This is in agreement with Pitcairn et al. (1990) and Zada et al. (2014), who reported weather parameters on codling moth population dynamics, but, in addition to other studies, here we investigated also the effect of altitude on the population.

Our study also points that the codling moth damage in orchards ranged from $1.4 \%$ to $84.3 \%$, mostly it was around $15-25 \%$ at harvest time which show extremely high loss of yield. We consider, this high damage correlated with insufficient control against codling moth and other pests. As determined in the study, growers have applied only once or twice a year insecticide in their orchards. Here, we suggest that biological control or other environmentally friendly methods such as mating disruption or microbial control immediately should be implemented in apple orchards by growers, because only $1-3 \%$ of infestation by codling moth may tolerable in intensive production (Pajač et al. 2011).

Our results clearly showed the population fluctuation of the C. pomonella throughout the season in Kyrgyzstan and also give about the right time for spray application for the effective management of this pest. Successful future management of codling moth will require detailed researches using other models, such as degree day model (DD). Because, the DD model is also used to assess phenology and seasonal occurrence of the $C$. pomonella effectively. 
Table 4

Infestation rate of codling moth in apple orchards in North Kyrgyzstan.

\begin{tabular}{lcccc}
\hline \multirow{2}{*}{ Sampling Site } & \multicolumn{4}{c}{ Infestation rate (\%) } \\
\cline { 2 - 5 } & mid-July 2019 & mid-September 2019 & mid-July 2020 & mid-September 2020 \\
\hline Chui-1 & 8,30 & 22,30 & 15,40 & 27,30 \\
Chui-2 & 52,60 & 84,30 & 61,10 & 77,10 \\
Chui-3 & 36,70 & 73,20 & 36,20 & 69,50 \\
YK-1 & 7,90 & 15,10 & 14,10 & 25,10 \\
YK-2 & 3,10 & 20,60 & 25,20 & 27,20 \\
YK-3 & 1,40 & 16,40 & 5,30 & 23,10 \\
YK-4 & 3,50 & 7,85 & 11,20 & 18,20 \\
\hline
\end{tabular}

\section{Acknowledgements}

We thank to Professor Hüseyin GÖÇMEN and Asst. Professor Şenol YILDIZ (Department of Plant Protection, Kyrgyz-Turkish Manas University) for their advice and encouragement during the conduct of the research. Also, we are grateful to Ainagul NASIROVA, Maksat KOZHOMKULOV (Tes-Centre, Bishkek) for their help during monitoring. This study is part of first authors' $\mathrm{PhD}$ thesis at Plant Protection Department, Selçuk University, Turkey. The first author thanks Scientific Research Unit (BAP) of Selçuk University for their financial support of this project (Project number: 19201017).

\section{References}

Aydoğan D, Ünlü L (2019). Determination of Population Development and Infestation Rates of Codling Moth [Cydia pomonella (L.) (Lep.: Tortricidae)] in Apple Orchards in Konya Province. Selcuk Journal of Agriculture and Food Sciences 33(1): 45-51.

Baker TC, Heath JJ (2005). Pheromones: Function and Use in Insect Control. In Comprehensive Molecular Insect Science (Vol. 6-6, pp. 407-459). Elsevier.

Barnes MM (1991). Codling moth occurrence, host race formation, and damage. In L. P. S. Van der Geest \& H. H. Evenhuis (Eds.), Tortricid Pests: Their Biology, Natural Enemies and Control, Vol. 5 (pp. 313-327). Amsterdam: Elsevier

Blomefield TL, Pringle KL, Sadie A (1997). Field observations on oviposition of codling moth, Cydia pomonella (Linnaeus)(Lepidoptera: Olethreutidae), in an unsprayed apple orchard in South Africa. African Entomology 5(2): 319-336.

Cornille A, Giraud T, Smulders MJ, Roldán-Ruiz I, Gladieux P (2014). The domestication and evolutionary ecology of apples. Trends in Genetics 30(2): 57-65.

Çelik H, Ünlü L (2017). Beyşehir (Konya) İlçesi Elma Bahçelerinde Elma İçkurdu [Cydia pomonella (L.) (Lep.: Tortricidae)]'nun Ergin Popülasyon Gelişimi ve Bulaşıklık Oranlarının Belirlenmesi. Harran Tarım ve Gıda Bilimleri Dergisi 21(3): 266-278.

Duan N, Bai Y, Sun H, Wang N, Ma Y, Li M, Chen X (2017). Genome re-sequencing reveals the history of apple and supports a two-stage model for fruit enlargement. Nature Communications 8(1): 1-11.

Fadamiro HY (2004). Monitoring the seasonal flight activity of Cydia pomonella and Argyrotaenia velutinana (Lepidoptera: Tortricidae) in apple orchards by using pheromone-baited traps. Environmental Entomology 33(6): 1711-1717.

Johnson J (2013). Pest control in postharvest nuts. In Improving the safety and quality of nuts (pp. 5687). Woodhead Publishing.

Knight AL, Hawkins L, Mcnamara K, Hilton R (2009) Monitoring and managing codling moth clearly and precisely. Good Fruit Grow 60: 26-27

Konurova KA, Turgunbaev KT, Alakunov AT (2017). Review on the distribution of codling moth in Kyrgyzstan. Annals of Kyrgyz Nation Agrarian University (2): 248-250. Original text in Russian: Конурова, Д. С., Тургунбаев, К. Т., \& Алакунов, А. Т. (2017). Обзор распространения яблонной плодожорки в кыргызстане. Вестник Кыргызского начионального аграрного университета им. КИ Скрябина (2): 248-250.

Luby J, Forsline P, Aldwinckle H, Bus V, Geibel M (2001). Silk road apples-collection, evaluation, and utilization of Malus sieversii from Central Asia. HortScience 36(2): 225-231.

Mamaev KA (1981). Pest and disease management of fruit crops. Moscow: Kolos, 1981 p.84-85. Original text in Russian: Мамаев К.А. Борьба с вредителями и болезнями плодовых, ягодных и овощных культур. - М.: Колос, 1981.- С.84-85

Mamay M, Yanık E (2013). Determination of Population Development and Infestation Rates of Codling Moth [Cydia pomonella (L.) (Lepidoptera: Tortricidae)] by Using Different Sampling Methods in Şanliurfa Province. Journal of Agricultural Sciences 19(2): 113-120.

Mills N (2005). Selecting effective parasitoids for biological control introductions: Codling moth as a case study. Biological Control 34(3): 274-282.

Pajač I, Pejić I, Barić B (2011). Codling moth, Cydia pomonella (Lepidoptera: Tortricidae)-major pest in apple production: an overview of its biology, resistance, genetic structure and control strategies. Agriculturae Conspectus Scientificus 76(2): 87-92. 
Pitcairn MJ, Zalom FG, Bentley WJ (1990). Weather factors influencing capture of Cydia pomonella (Lepidoptera: Tortricidae) in pheromone traps during overwintering flight in California. Environmental entomology 19(5): 1253-1258.

Reuveny H, Cohen E (2004). Resistance of the codling moth Cydia pomonella (L.)(Lep., Tortricidae) to pesticides in Israel. Journal of Applied Entomology 128(9-10): 645-651.

Riedl H, Croft BA (1978). The effects of photoperiod and effective temperatures on the seasonal phenology of the codling moth (Lepidoptera: Tortricidae) The Canadian Entomologist 110(5): 455-470.

Setyobudi L (1989). Seasonality of codling moth, Cydia pomonella (L.) (Lepidoptera: Olethreutidae) in the Willamette Valley of Oregon: role of photoperiod and temperature. Ph.D. Thesis, Oreg. State Univ., Corvallis.

Vasilev V, Pristavko VP (1970). A light-trap study of Laspeyresia pomonella 1. (Lepidoptera, Tortricidae) flight dynamics and population quantity. Vestnik
Zoology, (6), 63. Original text in Russian: Васильев, В. П., \& Приставко, В. П. (1970). К изучению динамики лёта и численности бабочек яблонной плодожорки с применением светоловушек. Вестник зоологии (6): 63.

Vreysen MJB, Carpenter JE, Marec F (2010). Improvement of the sterile insect technique for codling moth Cydia pomonella (Linnaeus)(Lepidoptera Tortricidae) to facilitate expansion of field application. Journal of Applied Entomology 134(3): 165181.

Welter SC (2009). Codling moth. In Encyclopedia of insects (pp. 174-175). Academic Press.

Witzgall P, Kirsch P, Cork A (2010). Sex pheromones and their impact on pest management. Journal of Chemical Ecology 36(1): 80-100.

Zada H, Saljoqi A, Farid A, Ullah F, Khan IA (2014). Influence of weather parameters on population dynamics of apple codling moth Cydia pomonella (Lepidoptera; Tortricidae) at Matta Swat valley. Sarhad J Agric 30: 351-356. 